\title{
As China Grows Strong
}

GERALD SEGAL

China's modernization is already rapidly improving the welfare of one quarter of mankind and changing communist ideology. But China is not only growing more stable and prosperous, it is also growing stronger. China's fourth modernization, national defence, is rarely treated in great detail, but it is increasingly clear that the reform of the defence sector is also having an important impact on both domestic and foreign policy. The process began in earnest in 1978 and by 1987 had completed its first stage of reorganization. At a major meeting of military and civilian officials in December 1986, the strategy for the next phase of military modernization was discussed. ${ }^{1}$ At the dawn of the new age of Chinese military power, it is essential to assess the implications of a stronger China for China itself, its neighbors, and the great power balance.

\section{Defence Modernization}

The modernization of China's national defence over the past eight years has been the most rapid and sustained since the founding of the People's Republic in 1949.2 Although it is still in its initial stages, defence modernization has clearly moved from the realm of merely innovative talk to implementation. To be sure, the process will be protracted, but it is clear that the commitment to real reform is genuine. What is more, this modernization has been achieved without an increase in the share of the budget spent on defence or wholesale re-equipment. Unlike during previous modernization as in the 1950s, the current improvements have been achieved without significant foreign assistance.

Military modernization has been primarily evident in four spheres. First, any real reform requires a modernized military doctrine before modern equipment is introduced. The new doctrine of "people's war under modern condition" is not a complete break with the past. But it has discarded obsolete principles that prevent China from making the best of its meagre resources in meeting the threat from a modern, mobile enemy. Among the major reforms is the notion that strategy and tactics are now formulated by military 
profesionals rather than Party bureaucrats. Second, except in the most unlikely case of total invasion, China has formally abandoned the notion of letting invaders strike deep into China so as to "swallow them up in a sea of people's war". The new theories of "active defence" and "positive defence" suggest that China may retreat in some circumstances, but will also stand and fight a conventional war to save high value targets such as cities and major industries. Combat is likely to be more destructive and "three dimensional", so China will rely more directly on its reorganized forces and less on the relatively untrained militia.

Thus the PLA has abandoned its primary reliance on ground forces and simple tactics in favor of more regularized combined arms operations. The result is a more mobile, fluid strategy that puts greater stress on complex, professional methods of command and control. Any attacker contemplating taking on the PLA will already have to count on paying a much higher cost.

The second sphere of modernization is in weapons and equipment. It is true that the defence budget has fallen as a proportion of the overall budget and has only begun to rise in real terms since 1985. But in recent years important savings have been made by reducing the size of the PLA by one quarter, a process due to be completed during 1987 when one million men will have been demobilized. Military planning has also been reorganised and professional control of decision-making has been strengthened. The military industries have been shaken up, reducing overlap and inefficiency. Large sections of military industry that previously produced civilian goods have been transferred to the civilian sector, thereby freeing parts of the defence budget for true military expenditure. China has also been earning billions of dollars during the past five years in arms sales abroad. More prosaic saving has been made by reducing waste, inefficiency and corruption, and by reshaping the bloated administration of the defence sector.

All these reforms have freed more money for new equipment. Little of substance has been purchased from abroad and China has opted for relatively inexpensive, defensive modern technology. The infantry has been given greater mobility by upgrading transport and modernizing its logistic "tail". The services have acquired a whole range of new weäpons, including anti-tank, anti-aircraft and anti-ship missiles. Follow-on models of tanks, aircraft and ships have been deployed or tested in recent years, all making use of modern technologies such as lasers and computers. Chinese troops, and especially the airforce and navy, have been acquiring equipment to 
increase their power projection. Long-range bombers, in-flight refuelling, long-distance naval replenishment and amphibious tanks and armoured vehicles have all been developed in recent years and suggest that Beijing is not merely interested in defending China. ${ }^{3}$ Nuclear weapons have also been modernized, with new ICBMs, SLBMs and MIRV technology all coming into production. In January 1987 China's new nuclear submarine passed its sea trials and began regular service. In sum, the PLA's equipment may not be first rate, but neither is it to be dismissed as third rate.

Third, the PLA has undertaken a wide range of internal reforms. The quality of leadership has been raised by bringing in younger, better trained professionals. With new systems of selection and promotion, the role of military academies has become central. Formal education has become an essential requirement of modern PLA officers and promotion depends on results.

Not surprisingly, in such an environment military training takes on added importance. Large scale manoeuvres to hone professionals skills have taken place in recent years. The more rigorous standards of modern war require more intelligent professionals, able to control combined arms operations and modern equipment.

Fourth, civil-military relations have been put on a more sensible footing. After the disaster of the Cultural Revolution when the PLA entered politics and politics entered the PLA, the combat strength of the armed forces was badly damaged. In recent years the PLA has willingly given up its powerful influence in civilian politics in the regions and in Beijing. Deng Xiaoping has shuffled regional military commanders to break up their fiefs. He has reorganised the military regions themselves, in June 1985, reducing to 7 the old system of 11 regions.

This return to the barracks has freed officers from the troublesome pressures of government and allowed them to concentrate on professional pursuits. This has only been possible because of the moderation and stability in civilian politics and the satisfaction Deng has given to professionals concerned about improving military standards. The once powerful political commissars have obviously been relegated to the peripheral role. Some older, more politically oriented officers have been opposed to relinquishing their power, but they are literally a dying problem. 


\section{PLA Strength and Domestic Politics}

These reforms in the PLA are in themselves far-reaching, but their significance goes beyond the armed forces. The impact has been first felt in China's general domestic politics. Chinese politics had been transformed in the 1960s when the armed forces were drawn into the civil fray of the Cultural Revolution. The PLA under its people's war strategy was also heavily involved in relief efforts, support for the Chinese economy and served as a revolutionary model. When the authority of the Party was smashed by Mao Zedong, the PLA restored order throughout China and found itself entrenched in regional and national politics.

The PLA had become the most interventionist of all armed forces in the Communist world, at least until the Polish crisis of the early 1980s. But in recent years the modernization of the armed forces has once again transformed the face of Chinese politics and brought the PLA much closer to the norm for an armed force in a Communist state. Today's PLA is less of a power broker and more of a normal participant in Chinese politics.

The PLA was only willing to surrender its leading role in Chinese politics because a number of elements was present. First, it was clear that the overall Chinese reforms were bringing stability. The PLA had entered politics because of instability and there was now no longer a need for it to restore or maintain order.

Second, the PLA was allowed to pursue its professional interests by a civilian regime that supported the notion of professionalism throughout society. The PLA was not going to be happy to be removed from power if it merely went back to empty barracks with little to do to engender pride. Third, the PLA was promised further resources to pursue its professionalism, although most of these were made available by cutting from other sectors of the non-professional PLA budget. In 1986 it appeared that the slimmed down, more professional armed forces were even getting more money in absolute terms.

This image of a modernized PLA, happy to return to the barracks and no longer a power broker in Beijing is a major change. The PLA has become a mirror of the society at large, pursuing modernization, minimizing politics, and getting on with business. ${ }^{4}$ To be sure, there remains some politics and factionalism within the PLA, as there is in other sectors of modern China. But it is not the politics of an armed forces pitted against civil authority. Rather 
there are debates between fast and slow modernizers, or pragmatists and ideologists within the PLA, just as these debates take place in other sectors of civilian life such as in education. These differences reach up to the Party in the region and the Politburo in Beijing.

The implications of these reforms in the PLA are sweeping. Above all, they help ensure that the political system remains stable, and with basic stability the armed forces can undertake the long term task of further modernization. In this sense, the success of China's entire modernization process is enhanced by the succes of the fourth, military, modernization. The stability of the political system is evident in changes in three main sectors. First, the drain on the exchequer of a bloated defence sector is reduced. The inefficiency of the defence industries is reduced by transferring them to streamlined civilian control under modern methods of management and with the bracing constraints of the market place. Defence spending itself has been reduced as a percentage of total government spending, thus freeing further funds for more profitable investment. Once again, the PLA contributes directly to the stability of China by enhancing modernization.

Second, by withdrawing the PLA from civilian politics, the dangers of regionalism are reduced. The independent kingdoms of the old military commanders are no longer a threat to the central government's ability to implement as well as formulate policy. However, in a country as large as China, regionalism will, of course, always remain a threat to a central government that wishes to harness the full, coordinated capability of all China.

Third, the withdrawal of the PLA from the rural economy helps reduce the distortion that its presence caused in recent years. Bereft of PLA support, failing and bankrupt ventures in the countryside can now be closed or reformed. Local peasants can develop their own transport and labour practices, free from the wider interests of a military forced to become involved in civilian politics.

There remains, of course, serious uncertainties about just how this process will affect modernization in the future. The extent to which the armed forces remain in control of certain industries has bedevilled Soviet planners looking for the best path to reform of a centrally planned economy. If the Soviet model is anything to go by, at least in the heavy industrial and electronic sectors, the PLA will continue to demand a major voice so as to ensure that its weapons can be produced when needed. The resulting distortion of a strong military voice in a command economy will then continue to hinder economic 
growth.

Furthermore, it is likely that the PLA will continue to be a conservative voice in civilian politics even if it does have its own internal divisions. If its primary concern remains stability in the inevitable roller-coasterlike reform process, it is understandable that the PLA will argue for caution. But conservative reformers in the PLA can still be reformers.

On balance, these trends suggest that the PLA will become a more normal, and therefore less important actor in Chinese domestic politics. While this may make Chinese politics less interesting to the outside observer, it is a positive trend for the PLA and for China. Thus one of the most successfull fruits of PLA modernization is greater stability in the political system and greater chance of success in the process of modernization. Especially in comparison to the instability and failure of past Chinese policies this new trend, and the PLA role within it, is of great consequence.

\section{The Strategy of Strength}

As China and its armed forces grow strong, the country also grows more important in international relations. Most analysis of this trend into the 21st century has focused on China as an international trade partner. However, a stronger China also affects the international balance of military power.

In Chinese defence culture, and indeed in terms of Communist ideology, the global balance of power is understood as the "correlation of forces". A stronger China has already begun to recognize the altered balance of power in a number of ways. First, China feels that its own strength is increasing in absolute terms by virtue of its more modern armed forces. Thus it is less likely that war can be imposed on China by an aggresive enemy and Beijing can look forward to a longer period of peace. Second, China's power has increased relative to others because its main rivals, the superpowers, have seen their power decline in important ways. For example, economic and social problems in Soviet Union have sapped Moscow's ability to continue its military buildup. The growth in American military power has also given the Soviet Union more to worry about. ${ }^{5}$

Third, China has also perceived that the world is a more complex and interdependent place than it first thought. Thus military power is less immediately useful as an instrument of foreign policy, especially for the superpowers. In East Asia, the growth of the Newly Industrializing Countries has demonstrated that the international economy is more interdependent, 
and less likely to see the use of military force. ${ }^{6}$

The implications of this changing correlation of forces have already begun to emerge. Most notably, China has declared since 1980 that world war is no longer inevitable. In the past, Beijing believed that the "forces for peace" were not necessarily sufficiently strong to withstand the "forces for war", especially the domineering superpowers. In the short term, the ability to delay or prevent war means that China has a breathing space to pursue its modernization in peace. Depending on how long this breathing space lasts, it is therefore unlikely that in the short term China would like to make use of what it sees as the more favorable balance of power to steal a march on its enemies.

In the medium or longer term, the absence of a world war will serve the interests of once-weaker states like China. While China probably does not expect to catch up in economic terms to the superpowers' level, it does have the example of a war-ravaged Japan that in 40 years of sustained growth now looks set to overtake the Soviet Union as the world's second largest economy. Thus the first implication of China's new strength is a greater sense of confidence that comes from having the opportunity to pursue effective modernization in peace.

Second, the changed correlation of forces also allows China to adopt a more flexible foreign policy. Its previous, failed strategy of the "Three Worlds" did not take into account just how intricate and intertwined the balance of power really was. Thus China has now come to understand that Third World conflict is not easily subject to superpower manipulation and that the much sought-after unity of the third world is a chimera. ${ }^{7}$ The most prosperous, and increasingly peaceful part of the developing world is in China's own backyard, East Asia. China could apply its new-found strengths in the balance of power nearer to home.

Perhaps the most important impact of the new balance of power was on China's ability to adopt a more balanced position between the superpowers. In the 1970s, when it perceived an imminent and more direct Soviet threat, China leaned more sharply to the United States. The fact that it leaned so far as to be nearly horizontal, led eventually to the reassessment of Soviet power and the international strategic balance. It is clear that as China grows strong, it also grows more independent of both superpowers, assuming the pivotal position in the great power triangle. In terms of the balance of power, this is the most enviable place to be, with the ability to play off one potential partner against the other. 


\section{Standing Up to the Superpowers}

China's new-found sense of strength has already begun to affect the global balance of power, and especially the pattern of Sino-Soviet relations. As part of its new military doctrine, the PLA has pulled back its crack troops several hundred miles from the frontier with the Soviet Union. By 1987 it will have completed the reduction of the PLA by one quarter, slashing one million men from the rolls. These unilateral arms control measures have had a profound impact on the balance of power in Asia.

China's arms control is undoubtely the single largest reduction in military power since Khrushchev trimmed one million men from the Soviet Army in the early 1960s. Since the majority of the Chinese troops is oriented towards meeting a perceived Soviet threat, it now appears that some 100.000-150.000 Chinese troops have been removed from the order of battle facing the Soviet Union. ${ }^{8}$ It is one of the great paradoxes of China's new strength that it can lead to a reduction rather than an increase in the threat of war. The Soviet fear of Chinese hordes sweeping across the empty frontier has been reduced as China modernizes and trims the PLA.

Of course, it was unlikely that China would pursue such unilateral arms control if it did not feel that its initial signs of detente were being reciprocated. The weave of recent Sino-Soviet detente is too complicated to be related here. But suffice it to say that the motives for and the process of Sino-Soviet detente have involved a range of ideological and economic, as well as military factors. In recent years the Soviet Union has been far-sighted enough to reciprocate the Chinese overtures with its own form of tacit arms control.

Since 1984-85 the Soviet forces in East Asia have been thinned out. While the number of Soviet divisions remains relatively constant, the readiness of those forces has been reduced, amounting to a withdrawal of some 100.000 troops. The Soviet Union has also seen that China's military reforms are producing a more professional armed forces, a trend likely to discourage the kind of adventurism and irrationality on the part of China that Moscow feared in the past. A more professional PLA makes for a more rational China in time of crisis.

To be sure, the Soviet forces remain a formidable threat. Despite Mikhail Gorbachev's July 1986 speech in Vladivostok, ${ }^{9}$ Moscow is unlikely to make more swingeing cuts in its armed forces without further encouragement 
from Beijing. But it remains true that this significant level of military detente has encouraged the broader process of Sino-Soviet detente. Gorbachev has thus been further nudged to explore the possibilities of the Soviet Union playing a more active part in the Pacific Century. In an atmosphere of cool superpower relations and warming Sino-Soviet relations, the role of recent changes in Chinese policy can be said to have a major impact on the strategic balance.

If the original Sino-Soviet split is understood as the single greatest shift in the strategic balance since 1945, then the warming of Sino-Soviet relations is nearly of equal importance. Chinese forces are clearly not in the league of the superpowers, but when their place in the strategic balance is shifted, they still will have an appreciable impact on the global balance of power.

Of course, China's military weight is felt primarily in its conventional forces. But changes in China's nuclear arsenal have also affected Soviet and superpower calculations. Since 1980, China has been reinforcing its nuclear arsenal in order to enhance its doctrine of minimum deterrence by denial with a wide range of nuclear forces. The enhancements have not left China with an appreciably larger arsenal, but it is more flexible and secure. Since China is the third largest nuclear weapons power, it is only natural that the superpowers would react to such developments.

The Soviet Union has long demanded a "China quotient" in superpower arms control in order to deal with the perceived Chinese threat. Equally, if less discussed, the United States has retained Chinese targets on the SIOP. Thus changes in China's nuclear forces have complicated superpower arms control, especially on INF. As the discussions at Reykjavik summit in October 1986 remind us, both superpowers are keen to retain sufficient nuclear weapons for use in the East Asia theatre.

Equally, China has watched the process of superpower arms control for signs of a carve-up that would harm the interests of "third parties". Most notable in this category is the question of SDI. Should such a defensive system be deployed by either superpower, China, together with other medium powers with limited nuclear forces, will find it necessary to increase its forces in order to ensure a reliable deterrent. ${ }^{10}$ On the other hand, should such an SDI be deployed along with deep cuts in the strategic arsenals of both powers, then China's limited nuclear weapons would constitute a far greater proportion of world totals.

Whatever the case, there are no signs that China foresees the need for vastly increased nuclear forces. From Beijing's perspective, growing military 
power will not be in the nuclear field except to maintain a nuclear force that can carry out its minimum deterrent of a range of threats within a doctrine of deterrence by denial.

It is notable that the longer range and greater flexibility of China's nuclear weapons enhances its ability to strike at either superpower. The United States has not commented openly on the implications of China's new capability, for when the overall total of nuclear weapons is considered, China remains a marginal actor. What has been of greater interest to the United States is the shift to greater independence in Chinese foreign policy that has been part of Beijing's increased sense of international confidence.

In recent years this independence has been manifest in the more open Chinese attacks on United States policy in the third world and on NorthSouth relations. China has also established closer relations with American enemies, including Cuba and Nicaragua. Some Americans have called this China's "two Americas" policy, reminding Beijing of its criticism of the United States for trying to maintain good relations with both Taiwan and China. China has also excelled in tweaking the American superpower's nose. When seeking to curry favor with South Pacific states, China withdrew an invitation to the United States navy to visit Chinese ports unless the ships concerned declared they were not carrying nuclear weapons. ${ }^{11}$ Although the trip eventually did take place in October 1986, China had demonstrated its willingness to take symbolic actions in support of its fine words of foreign policy independence.

The Reagan administration has been more willing than most to put up with Chinese tactics because of changes in the United States' own priorities in East Asia. The shift to greater concern with offshore power in support of Japan, Taiwan and trade routes in general, has allowed the United States to be more relaxed in its reaction to China. In addition, the Reagan administration has offered stronger support to Taiwan by allowing "private" firms to sell arms while official government-to-government sales are cut back. $^{12}$ Chinese reaction has been quietly brushed aside as the PRC-US military contacts continue.

While it is true that the impact of a stronger China has so far largely served United States interests - for example in helping contain the Soviet Union - the expected economic bonanza has failed to materialize. China has largely refused to buy American weapons on a large scale, although it has been looking longingly at catalogues on the shelf for years. In some cases China has even found it preferable to steal technology from the United States in 
order to speed up military modernization at home.

Into the medium and longer term there is even greater reason for American concern about the implication of a stronger China. A China less worried about a Soviet threat and increasingly concerned about a growing independence movement in Taiwan might well find itself in direct conflict with United States policy. In fact, it is in the regional sphere that the implications of China's new strength seem most destabilizing.

\section{Shifting Asian Balances of Power}

While China has usually been described as a great power, its most effective foreign policy reach barely extends to the outer fringes of Asia. Its great power status was largely based on others' perceptions of Chinese potential, and the fact that many of the international conflicts took place on China's doorstep. But even in the period when China was weak, it still managed to wage several wars in Asia. China has lost more men in combat than any other great power since 1945. ${ }^{13}$ As China grows strong and looms even larger over its Asian neighbours, the balance of power in Asia is bound to shift.

China's new self-confidence is already evident in its approach to the still unresolved Korean conflict. In the days of greater insecurity, China vied with the Soviet Union for every inch of influence in North Korea. The more confident China has not been deeply upset by an increase of Soviet sway in Pyongyang because China itself is less fearful of Soviet intentions. What is more, China recognizes the Soviet stake in a stable Korea and their joint interest in making their mutual North Korean ally less burdensome or risky. China has even been so bold as to develop an annual trade with South Korea worth some \$1bn per year, far more than Sino-North Korean trade. ${ }^{14} \mathrm{~A}$ stronger, more secure China apparently has less stake in supporting the dangerous ambitions of its allies - a policy reminiscent of Soviet warnings to China in the 1950s about pursuing an aggresive policy towards the United States.

However, a stronger China is not necessarily less adventurous if the stake is Chinese rather than allied interest. China has more unsettled territorial claims than any other major power, disputing borders with the Soviet Union in the north, Japan and Taiwan in the east, and Vietnam and India in the south. China's military instrument has usually been used only when it was strong enough to take what it claimed. When the will and the ability were 
present, as in 1962 against India or 1974 in the Paracels, China moved swiftly. In 1979 , the will was not backed by the ability to carry out an effective military operation and China failed to "teach Vietnam a lesson."

Currently, China is restained from using force for a variety of reasons. In the Soviet case, China finds that detente is better route to meeting its claim; Gorbachev recognized the Chinese case on the river frontier in July 1986. Territorial claims against Japan are put on the back burner because Japan is far too important as a trading partner and crisis over disputed islands would undermine Chinese creditworthiness. China is deterred from forcing the pace in Taiwan because it hopes the island will go the route of Hong Kong, and fall into its lap under the banner of "one country, two systems". Yet Hu Yaobang has already made clear that China does not rule out the use of military force to regain Taiwan. He has even suggested that the passage of time is precisely what is needed to convince Taiwan that China is strong enough to get its way. ${ }^{15}$ China's growing naval strength and ability to deploy more force at longer ranges suggest that China has not ruled out military operation against Taiwan.

The Taiwan problem remains perhaps the most serious threat to China's image as a peaceful participant in the Pacific century. With a continuing economic boom and the passage of time in Taiwan, reunification becomes less, rather than more likely. There is nothing inevitable about a single nation of all Chinese (note the 19 Arab states) and it would be foolish to expect China to sit idly by while Taiwan drifts further away. Only then will the challenge of China's growing strength force the United States to react decisively.

But if the Americans will eventually have to face the implication of Chinese strength, so will the Soviet Union. China's attack on Vietnam and Soviet deterrence of wider Chinese actions in 1979 suggest just how involved Moscow may have to become. So far, Vietnam has been able to stand largely on its own against a relatively weak PLA. Should the Kampuchean question not be resolved before China's strength becomes convincing, then a "second lesson" cannot be ruled out. Vietnam, like Taiwan, has a great deal to fear from a more powerful China that has managed to sever the links between its smaller neighbors and their superpower patron.

Further afield, it is China's growing naval strength and evolution of a "blue water" navy that poses the greatest risk of instability in Asia. As Chinese ships sail out to the South Pacific and the Indian Ocean, a number of Southeast and South Asian states have reason to be concerned. Indonesia 
and India have long feared the role of a powerful China sailing into their troubled waters. Both see themselves as regional powers with positions vulnerable to Chinese expansion. The more China throws its weight around in Southeast Asia or against Taiwan, the more other ASEAN states will fear a stronger China. It is one thing to have a flawed China as a counterweight to superpower influence, but quite another when the superpowers are seeking Chinese favor and Beijing is more able and willing to intervene in the region. As China tests its nuclear missiles in the Pacific and sails its SSBNs into the Indian Ocean, it is not likely to project a truly peaceful image to those already worried for ethnic and geostrategic reasons about its growing strength. If China is not on its best behavior as it grows strong, it will also grow more threatening to its neighbors. That is the volatile stuff of arms races and crises.

\section{The Long Arm of China}

A key characteristic of a great power becoming a superpower is the lengthening reach of its foreign and security policy arm. China's foreign policy has long been interested in events in far-off Africa or the Middle East, but has been restricted by its inability to give large scale military aid to countries where opportunities for greater influence present themselves. Thus the outbreak of crisis in the developing world often left China frustrated, with fine words but little scope for action. However, as China grows stronger its reach is extending further into the distant developing world.

By the late 1970s China's third world policy was in a state of confusion. Its revolutionary model had been abandoned, and replaced with a hodgepodge of polities, often placing China in alliance with reactionaries and allies of the United States or even South Africa. But with new pragmatism at home as a model, China took another look at the developing world. It saw great confusion in local politics, but the possibility of monetary reward. Thus a stronger China formulated a new strategy for the 1980s.

Instead of offering only advice to states in conflict, it would also offer arms. But unlike most previous arms transfers, China was now prepared to sell rather than give the weapons away. ${ }^{16}$ Chinese policy required three things, 1) wars to exploit the need of combatants for the tools of the trade, 2) rich combatants or ones with rich friends who could afford to pay for the hardware, 3) combatants with requirements for inexpensive, but hardy 
weaponry for the rough conditions of conflict in the developing world. China found such a mix in the Iran-Iraq war and began earning billions every year by selling arms to both sides of the battle lines.

China's arms industry was reorganized and China began attending international arms fairs. In November 1986 a huge arms fair was held in Beijing, mainly for the third world buyers. As part of this globalization of the Chinese arms industry, it has begun co-production deals with various third world states, including some in far-off Latin America. Unlike Britain and France, China does not seek to supply weapons with the same level of sophistication as the superpowers. But it has spotted a market niche in bargain basement weapons. With the rising cost of modern war, that market looks like growing, and reinforcing China's dubious honor of being the world's fourth largest arms exporter.

Of course, China is unlikely to earn lasting influence from its arms sales. Like the superpowers, China knows that while the allegiance of developing states can be "rented", it can rarely be bought for long. Hence perhaps the shift to more cynical arms sales such as those to both sides of a conflict. If another Angola-type conflict were to arise and a combatant needed weapons, China could stay in the arms game, unlike in 1974 when it had to retreat in the face of the superior ability of the superpowers to deliver the arms that were needed. But unless the combatants could pay, it is unlikely that China would manipulate successfully its new potential for arms transfers. China's longer reach, if it remains primarily for profit rather than political gain, will be less threatening to the interests of others powers.

What might be more challenging is the new Chinese model of military modernization for the developing world that seems to be emerging as China grows strong. The message is three fold. First, development is only possible if the armed forces are reduced. Second, the soldiers should concentrate only on soldiering and not intervene in politics. Third, developing states need a peaceful international environment with more open, outward oriented economies. A less confrontational approach to the outside world is to be much preferred.

Needless to say this is not a message that the military dictatorships in the developing world want to hear. It would frequently undermine the ruling elite and force developing states to focus on their own responsibilities rather than seeking the excuse of foreign wars or falling back on sterile attacks on the developed North. This Chinese message is more in keeping with the recent trend in East Asia where developing states have achieved remarkable 
progress by avoiding war and concentrating on trade and economic growth.

On balance, a stronger China is one with wider global commitments, but with less responsibilities and caution. It is a China more focussed on domestic stability and growth and the possibilty of improving its regional position in East Asia. In the short term, a stronger China is a more peaceful China. But in the longer term there is strong evidence that China will not sit idly by while the NICs and Japan keep moving the goal-posts of successful modernization. The temptation to imperialism that was so fatally attractive to Japan a century ago may yet beckon to Beijing.

Gerald Segal is Lecturer in Politics at the University of Bristol, England.

\section{NOTES}

1 For various reports on the enlarged meeting of the Military Affairs Committee in December 1986 see BBC, Summary of World Broadcasts (SWB), Far East (FE), 8453, B/II, 4-7.

2 This section relies heavily on Ellis Joffe and Gerald Segal, "The PLA Under Modern Condition", Survival, August 1985. See also the forthcoming booklength study of Chinese military reforms by Ellis Joffe, Marching to Modernisation (London: Weidenfeld, 1987).

3 Recent details in Liaowang, December 22, 1986 in BBC, SWB, FE, 8453, B/II, 79.

4 David Goodman, "Domestic Reforms" in David Goodman, Martin Lockett, Gerald Segal, The China Challenge (London: Royal Institute of International Affairs, Chatham House Paper, No. 32, 1986).

5 Shijie Zhishi, No. 21, November 1, 1986 in FBIS-CHI-86-221 and Guoji Wenti Yanjiu, No. 4, October 13, 1986 in FBISCHI-86-214.
6 For example, Red Flag, No. 13, July 1, 1986 in FBIS-CHI-86-144.

7 Lillian Craig Harris and Robert Worden (eds.), China and the Third World (Dover Mass: Auburn House, 1986).

8 Details in Gerald Segal (ed.), Arms Control in Asia (London: Macmillan, 1987) and Gerald Segal, Sino-Soviet Relations After Mao (London: IISS, Adelphi Paper, No. 202, 1985).

9 Gorbachev's speech, reported on the Moscow Home Service, July 28, 1986, in BBC, SWB, Soviet Union, No. 8324, C/1-18.

10 Alastair Johnston, China and Arms Control (Ottawa: Canadian Centre for Arms Control and Disarmament, Aurora Papers, No. 3, 1986) and Gerald Segal "China and Arms Control", The World Today, August 1985.

11 Jonathan Pollack, The Lessons of Coalition Politics (Santa Monica, California: The Rand Corporation R-3133 AF, 1984).

12 Far Eastern Economic Review, July 24, 1986. 
13 Gerald Segal, Defending China (Oxford: Oxford University Press, 1985).

14 Jonathan Pollack, "US-Korean Relations: The China Factor", North East Asian Affairs, Vol. 4, No. 3 (Fall 1985).
15 Hu Yaobang in a May 10, 1985 interview to Hong Kong's Pai Hsing, No. 97, June 1, 1985, in FBIS-CHI-85-106.

16 Yitzhak Shichor, "China and the Middle East" in Gerald Segal and William Tow (eds.), Chinese Defence Policy (London: Macmillan, 1984). 